\title{
SOIL CARBON AND NUTRIENT RECOVERY AFTER HIGH-SEVERITY WILDFIRE IN MEXICO
}

\author{
Shatya D. Quintero-Gradilla ${ }^{1 *}$, Felipe García-Oliva², Ramón Cuevas-Guzmán², \\ Enrique J. Jardel-Peláez ${ }^{3}$, and Angelina Martínez-Yrizar ${ }^{4}$ \\ ${ }^{1}$ Centro Universitario de la Costa Sur, Universidad de Guadalajara, \\ Avenida Independencia Nacional 151, Autlán de Navarro, Jalisco, México, C.P. 48900 \\ ${ }^{2}$ Instituto de Investigaciones en Ecosistemas y Sustentabilidad, \\ Universidad Nacional Autónoma de México, \\ Antigua Carretera a Pátzcuaro 8701, Morelia, Michoacán, México, C.P. 58190 \\ ${ }^{3}$ Departamento de Ecología y Recursos Naturales, \\ Centro Universitario de la Costa Sur, Universidad de Guadalajara, \\ Avenida Independencia Nacional 151, Autlán de Navarro, Jalisco, México, C.P. 48900 \\ ${ }^{4}$ Instituto de Ecología, Universidad Nacional Autónoma de México, \\ Boulevard Colosio sin número, Hermosillo, Sonora, México, C.P. 83000 \\ *Corresponding author: +52-317-382 5010, ext. 7158; e-mail: shatya@yahoo.com
}

\section{ABSTRACT}

Fire severity can increase above historical levels due to factors such as human-derived fire suppression and climate change. Studies about the effects of high-severity fires on soil carbon and nutrients in pine forest at tropical latitudes are still rare. We analyzed the changes in carbon $(\mathrm{C})$, nitrogen $(\mathrm{N})$, and phosphorus $(\mathrm{P})$ contents in the organic layer and the top mineral soil layer in a post-fire chronosequence of Pinus douglasiana Martínez-dominated forest stands in central-western Mexico $8 \mathrm{yr}, 28 \mathrm{yr}$, and $60 \mathrm{yr}$ following a high-severity fire. We found that fire significantly affected the total $\mathrm{C}, \mathrm{N}$, and $\mathrm{P}$ contents in the organic layer, explained mainly by mass losses. We did not detect differences in $\mathrm{C}, \mathrm{N}$, and $\mathrm{P}$ contents $\left(\mathrm{Mg} \mathrm{ha}^{-1}\right)$ in the mineral soil, but $\mathrm{C}$ and $\mathrm{N}$ concentrations $\left(\mathrm{mg} \mathrm{g}^{-1}\right)$ in-

\section{RESUMEN}

La severidad de los incendios podría aumentar por encima de los valores históricos como resultado de acciones humanas como la supresión de incendios y el cambio climático. Estudios sobre el efecto de los incendios de alta severidad sobre el carbono y los nutrientes almacenados en suelos de bosques de pino en latitudes tropicales, son escasos. En este estudio analizamos los cambios en los contenidos de carbono $(\mathrm{C})$, nitrógeno $(\mathrm{N})$ y fósforo $(\mathrm{P})$ almacenados en la capa orgánica del suelo y en la capa superficial del suelo mineral, en una crono-secuencia post-incendio en bosques dominados por Pinus douglasiana Martínez, en el centro-occidente de México, 8 años, 28 años, y 60 años después de incendios severos. Los incendios afectaron significativamente los contenidos de $\mathrm{C}, \mathrm{N}$ y $\mathrm{P}$ en la capa orgánica, explicado principalmente por la pérdida de masa. No hubo diferencias en los contenidos de $\mathrm{C}, \mathrm{N}$ y $\mathrm{P}$ $\left(\mathrm{Mg} \mathrm{ha}^{-1}\right)$ en el suelo mineral, mientras que la 
creased with stand age. This can be explained by the high levels of tree mortality that occur during high-severity fires, depleting litter inputs to the soil. We observed a fast recovery of $\mathrm{C}$, $\mathrm{N}$, and $\mathrm{P}$, perhaps resulting from the high capacity of Pinus douglasiana to regenerate following high-severity fires. This can be associated with high metabolic rates of forests in tropical latitudes, which, given their climate and soil conditions, favor higher rates of vegetation growth and, thus, faster rates of organic $\mathrm{C}$ inputs and soil organic $\mathrm{C}$ accumulation. concentración de $\mathrm{C}$ y N ( $\left.\mathrm{mg} \mathrm{g}^{-1}\right)$ se incrementó con la edad del rodal. Esto puede ser explicado por la alta mortalidad de árboles provocada por los incendios severos, lo que disminuyó la entrada de materia orgánica al suelo. Se registró una rápida recuperación de los contenidos de $\mathrm{C}, \mathrm{N}$ y $\mathrm{P}$ probablemente como resultado de la alta capacidad de Pinus douglasiana para regenerar después de incendios severos. Lo anterior puede estar asociado con las altas tasas metabólicas de los bosques en latitudes tropicales, dadas las condiciones climáticas y de suelo que favorecen mayores tasas de crecimiento de la vegetación y de incorporación y acumulación de $\mathrm{C}$ en el suelo.

Keywords: biomass, duff, fire effects, litter, Mexico, nitrogen, phosphorus, pine forests, Sierra de Manantlán

Citation: Quintero-Gradilla, S.D., F. García-Oliva, R. Cuevas-Guzmán, E.J. Jardel-Peláez, and A. Martínez-Yrizar. Soil carbon and nutrient recovery after high-severity wildfire in Mexico. Fire Ecology 11(3): 45-61. doi: 10.4996/fireecology.1103045

\section{INTRODUCTION}

Fire affects forests globally (Agee 1993, Fulé and Covington 1997, Alauzis et al. 2004, Russell-Smith and Yates 2007, Scott et al. 2014), changing various components of these ecosystems, such as carbon and nutrient dynamics (Johnson and Curtis 2001, Carter and Foster 2004). Fire severity can increase with variations in fuels, topography, and weather conditions (Agee 1993), and if the time between fires increases due to factors such as human-derived fire suppression, fuels accumulate and high-severity fire can occur (Fulé and Covington 1997), promoting forest stand replacement processes (Smithwick et al. 2005).

During the nineteenth and most of the twentieth centuries, fire suppression was a generalized management approach in fireprone forests worldwide, including Mexico, to protect timber resources and rural communities (Covington and Moore 1992, Agee 1993, Jardel et al. 2009, Rodríguez-Trejo et al.
2011). Cessation of frequent low-severity fires can increase severity in the next fire event, due to higher biomass accumulation (Agee 1993); in addition to this, global climate change scenarios predict higher temperatures and more droughts in some regions of the world, which may lead to high-severity fire proliferation (Wotton and Flannigan 1993, Westerling et al. 2006). Thus, studies that generate quantitative data that help understand the effects of high-severity fires on soil carbon and nutrients are critical to improve and validate global carbon cycle models and to provide information that supports fire management (Badia et al. 2014).

The organic layer and soil surface represent important sources of nutrients in forest ecosystems (Switzer et al. 1979, Boerner 1982). High-severity fires cause high tree mortality and reach high temperatures $\left(675^{\circ} \mathrm{C}\right)$ in the organic layer, consuming most or all of it (Overby et al. 2003). These fires can transfer considerable heat to the mineral soil, re- 
ducing soil carbon $(\mathrm{C})$ and nitrogen $(\mathrm{N})$ stocks (Johnson and Curtis 2001), as these elements volatilize at $200^{\circ} \mathrm{C}$ (Neary et al. 1999 , Certini 2005). Thus, high-severity fires can negatively impact carbon and nutrient stocks (Neary et al. 1999), decreasing forest productivity (Covington and Moore 1992, Georgiadis 2011, Bento-Goncalves et al. 2012, Powers et al. 2013).

Studies report losses higher than $75 \%$ of C and $\mathrm{N}$ stocks in the organic layer following high-severity fires (Baird et al. 1999, Neary et al. 1999, Murphy et al. 2006, Neary and Overby 2006). Since phosphorus (P) requires temperatures above $770{ }^{\circ} \mathrm{C}$ to volatilize (Neary et al. 2005), only $50 \%$ to $70 \%$ is lost during combustion in high-severity fires, and the residual $\mathrm{P}$ returns to the soil as ash (DeBano and Conrad 1978, Murphy et al. 2006). However, residual phosphorus is vulnerable to hydric or wind erosion, and can be lost rapidly following a fire (Giardina et al. 2000).

Mineral soil layers appear to be less affected by high-severity fire, as only the first $5 \mathrm{~cm}$ of depth generally register a small amount of the heat generated during the fire, rarely exceeding $200^{\circ} \mathrm{C}$ (Neary et al. 1999 , Certini 2005). However, losses of up to $50 \%$ of total $\mathrm{C}$ and $\mathrm{N}$ content in the top mineral soil layer have been documented as a direct result of the combustion of soil organic matter (SOM) in different forest soils (Kutiel and Naveh 1987, Fernández et al. 1997, Baird et al. 1999, Murphy et al. 2006, Martín et al. 2012). Furthermore, subsequent losses of $\mathrm{C}$ and $\mathrm{N}$ may occur due to increased SOM mineralization and surface soil erosion (Neary et al. 2005). In contrast, total P in soil may increase by $100 \%$ to $300 \%$ (Kutiel and Naveh 1987, Giardina et al. 2000, Martín et al. 2012), mostly due to ash inputs, organic $\mathrm{P}$ mineralization, and solubility of the occluded $\mathrm{P}$ as a result of chemical changes to the soil solution (Kutiel and Naveh 1987, García-Oliva and Jaramillo 2011).

Fire causes temporary $\mathrm{N}$ and $\mathrm{P}$ mineralization in soils (Wan et al. 2001, Certini 2005), increasing the availability of these nutrients for plants and microorganisms (Grove et al. 1986, Kutiel and Naveh 1987, Serrasolsas and Khanna 1995, Murphy et al. 2006). While this contributes to vegetation regeneration, decreased availability in the years following the fire is due to plant assimilation, microbial immobilization, and losses from leaching and erosion (Kutiel and Naveh 1987, Murphy et al. 2006, García-Oliva and Jaramillo 2011, Chen and Shrestha 2012, Guénon et al. 2013).

Post-fire recovery of soil $\mathrm{C}, \mathrm{N}$, and $\mathrm{P}$ relies on organic matter accumulation, which is tied to forest productivity. Litter accumulates relatively quickly during stand development, reaching a maximum, and remaining relatively constant when inputs equal outputs through litter decomposition (Switzer et al. 1979, Seedre et al. 2011). Smith and Heath (2002) reported that, for several forests in the USA, equilibrium is reached 20 to 80 years following a fire event; recovery time depends on bioclimatic conditions, plant productivity, plant community composition, and post-fire successional dynamics (Switzer et al. 1979, Certini 2005, Smithwick et al. 2005, Gurmesa et al.2013).

Recovery of $\mathrm{C}, \mathrm{N}$, and $\mathrm{P}$ in surface mineral soil layers depends on the quantity of organic matter produced by the vegetation established after the fire. Nitrogen recovery can occur at faster rates, even exceeding pre-fire levels, after the establishment of $\mathrm{N}$-fixing plants (Carter and Foster 2004, Johnson et al. 2004). In contrast, soil $\mathrm{P}$ recovery depends mainly on ion leaching and occlusion processes within the mineral soil (Kutiel and Naveh 1987); soil texture is a key factor in this process, as clays have a higher capacity to form stable compounds with organic molecules and metals within the soil matrix (Six et al. 2002).

Nonetheless, soil $\mathrm{C}, \mathrm{N}$, and $\mathrm{P}$ recovery rates following high-severity fires are variable, depending on amounts of organic matter input, which in turn depends on temperature, moisture, soil type, plant species, and nutrient 
availability (Post and Kwon 2000). For instance, Baird et al. (1999) reported recoveries of $70 \%$ of soil organic carbon (SOC), and $32 \%$ of soil $\mathrm{N}$ within the first year following a high-severity fire in a Pinus ponderosa P. Lawson and $P$. ponderosa C. Lawson forest. Alauzis et al. (2004) observed that, four years after a fire in Nothofagus pumilio (Poepp. and Endl.) Krasser forests, concentrations of $\mathrm{C}$ and $\mathrm{N}$ were $52 \%$ and $22 \%$ lower than in soils without fires. In contrast, LeDuc and Rothstein (2007) observed that in Pinus banksiana Lamb. forests, SOC recovered to pre-fire levels six years after the fire, while $\mathrm{N}$ concentrations were $36 \%$ lower than those in control stands.

While the immediate effects of high-severity fires on soil properties have been widely documented, their mid- and long-term effects must be further investigated (Wan et al. 2001, Duran et al. 2010). Thus, the objective of this study was to analyze changes of $\mathrm{C}, \mathrm{N}$, and $\mathrm{P}$ contents in the soil organic layer and the top mineral layer in a chronosequence of Pinus douglasiana Martinez-dominated forests, $8 \mathrm{yr}$ and $28 \mathrm{yr}$ following high-severity fires, and in mature stands without fire for more than 60 years, in central-western Mexico. The hypotheses of this work were as follows: a) C, N, and $\mathrm{P}$ in the organic layer and top mineral soil will increase with stand age after a high-severity fire, until they reach values similar to those of mature stands not affected by high-severity fires; and b) the recovery of these elements in the organic layer will be at a faster rate than in the mineral soil layer.

\section{METHODS}

\section{Study Area}

The study was conducted in Las Joyas Research Station (LJRS), located in the central-western portion of the Sierra de Manantlán Biosphere Reserve (SMBR; 19 $9^{\circ} 14^{\prime} 49^{\prime \prime} \mathrm{N}$ to $19^{\circ} 37^{\prime} 30^{\prime \prime} \mathrm{N}$, and $104^{\circ} 14^{\prime} 49^{\prime \prime} \mathrm{W}$ to $104^{\circ} 18^{\prime}$ $\left.16^{\prime \prime} \mathrm{W}\right)$. This reserve is a federally protected area located in the state of Jalisco, in central-western Mexico. The station covers 1245 ha, with altitudes that range between $1500 \mathrm{~m}$ and $2242 \mathrm{~m}$. Climatic conditions in the study area correspond to the lower montane subtropical moist forest of the Holdridge Life Zone System (Jardel et al. 2004b). Climate in LJRS is classified as sub-humid temperate with summer rains (June to September). Mean annual rainfall is $1826 \pm 94 \mathrm{~mm}$, and the potential evapotranspiration ratio (potential evapotranspiration:annual precipitation) ranges between 0.5 and 0.6. Mean annual temperature is 15 $\pm 2^{\circ} \mathrm{C}$, ranging from $12.8^{\circ} \mathrm{C}$ in January, the coldest month, to $20^{\circ} \mathrm{C}$ in May, the warmest month (Jardel et al. 2004b).

The geological substrate of LJRS consists of Tertiary extrusive igneous rocks like basaltic porphyries, basalts, andesitic basalts, and volcanic tuffs. A typical soil catena in the area is a gradient from Inceptisols in mountaintops and upper slopes to Alfisols in lower slopes, and Ultisols in hollows and stream banks (Martínez et al. 1993, Jardel et al. 2004b).

Vegetation cover in the area is a mosaic of pine-oak forests associated with convex landforms (mountaintops and upper slopes), mixed hardwood forests (bosque mesófilo de montaña or cloud forest) in concave landforms (ravines and hollows), mixed pine-hardwood forests in intermediate conditions, and secondary scrub in abandoned agriculture fields (Jardel et al. 2004a). Pinus douglasiana is the dominant species in pine-oak and pine-hardwood forests.

The area has a long history of human influence through slash and burn agriculture in small plots, extensive livestock grazing, and logging; these activities ended in 1987, following the designation of LJRS as part of one of the core zones of SMBR (Jardel 1991). Since biodiversity conservation and restoration are central goals of LJRS, fire suppression is used to encourage the recovery of forest cover through natural regeneration of mixed hardwood forests and mixed pine-hardwood forests. 
Most fires in the SMBR occur between April and early June, at the end of the dry season. Fires in the area are relatively small (mean: 189 ha, mode: 50 ha); the most common ignition factors are human-related activities, but fires originated by lightning have also been recorded (Balcázar 2011). Frequent, low-severity, surface fires characterize the historical fire regime in the pine-oak forest, with mean fire intervals ranging from 3 to 12 years (Jardel 1991, Llamas-Casillas 2013, Cerano-Paredes et al. 2015), similar to intervals recorded in northwestern Mexico and the southwestern USA (Stephens and Fulé 2005).

Fire suppression in LJRS has led to decreased fire frequencies and accumulation of fuels. Organic matter and woody debris loads for stands without fires in 20 years have been estimated, respectively, at $37 \mathrm{Mg} \mathrm{ha}^{-1}$ to $58 \mathrm{Mg}$ $\mathrm{ha}^{-1}$, and $31 \mathrm{Mg} \mathrm{ha}^{-1}$ to $38 \mathrm{Mg} \mathrm{ha}^{-1}$ (Alvarado-Celestino et al. 2008). These conditions can lead to intense surface fires with high tree mortality (basal area loss $>70 \%$ ) and consumption of most or all of the organic soil layer, caused by smoldering combustion and torching, opening 1 ha to 40 ha patches (as recorded following fires in 1983 and 2003) where succession is restarted (Jardel 1991, Llamas-Casillas 2013). For this study, we selected sites that burned at high-severity in the 1983 and 2003 fires.

\section{Sampling Design}

To evaluate the effects of stand-replacing fires on total $\mathrm{C}, \mathrm{N}$, and $\mathrm{P}$ contained in the soil organic layer and the top mineral layer, we compared stands in a post-fire chronosequence, $8 \mathrm{yr}$ and $28 \mathrm{yr}$ following a fire, with mature stands without high-severity fire for more than 60 years. These three conditions are referred to hereafter as $8 \mathrm{yr}$ old, $28 \mathrm{yr}$ old, and $60 \mathrm{yr}$ old stands, and coincide with three stand development stages: stand initiation, stem exclusion, and understory reinitiation, respectively. The $60 \mathrm{yr}$ old stands had not had low-severity fires since the protected area was established in 1987 and represent late-successional seres in the absence of fire.

Our space-for-time substitution design relies on the assumption that all variation among sites is due to differences in time since disturbance (Yanai et al. 2003); we use a nested sampling design to help account for violations to these assumptions. If sites differed in organic matter and soil $\mathrm{C}, \mathrm{N}$, and $\mathrm{P}$ due to inherent landscape variability (rather than time after disturbance), we expected to capture that variability in our sample units (Allen et al. 2010). We selected three independent stands for each age group ( $8 \mathrm{yr}$ old, $28 \mathrm{yr}$ old, and $60 \mathrm{yr}$ old); within each we established three $500 \mathrm{~m}^{2}$ circular plots (12.62 m radius) with a minimum 50 $\mathrm{m}$ separation between their centers. Stands were $\sim 0.5 \mathrm{~km}$ to $2.4 \mathrm{~km}$ apart to minimize the impact of spatial autocorrelation, and we did not sample stands of the same age class in close proximity to one another.

To minimize the effect of site conditions, stands were located in the same altitudinal range $(1950 \mathrm{~m}$ to $2150 \mathrm{~m})$, within the same soil type unit (Alfisols), in the mid-portion of north-facing slopes dominated by Pinus douglasiana $(>70 \%$ basal area) (Table 1). While mean tree density did not differ among stands, tree basal area in the $8 \mathrm{yr}$ old stands was four times lower than in the $28 \mathrm{yr}$ old and $60 \mathrm{yr}$ old stands, an expected effect of high-severity fires, which strongly alters the forest structure (MacKenzie et al. 2004).

\section{Organic Layer and Mineral Soil Sampling}

We collected organic and top mineral soil samples in the dry season, between January and June 2011, the highest accumulation period for the organic layer in the region (Covaleda 2008). We divided the organic layer into two sub-layers: litter layer (LL) and duff layer (DL). The LL is formed of plant residues (excluding woody debris) that keep their structure and have an identifiable origin, and the DL in- 
Table 1. Tree density and basal area in $8 \mathrm{yr}$ old, $28 \mathrm{yr}$ old, and $60 \mathrm{yr}$ old stands of Pinus douglasiana following high-severity fires in central-western Mexico. Values represent averages for each stand, with standard error in parentheses; $\mathrm{a}$ and $\mathrm{b}$ show significant differences between means $(P<0.05)$ with the post-hoc Tukey test.

\begin{tabular}{lccc}
\hline & \multicolumn{3}{c}{ Stand age } \\
\cline { 2 - 4 } Structural variables & $\mathbf{8} \mathbf{~ y r}$ & $\mathbf{2 8} \mathbf{~ y r}$ & $\mathbf{6 0} \mathbf{~ y r}$ \\
\hline Density $\left(\right.$ trees $\left.\mathrm{ha}^{-1} \geq 2.5 \mathrm{dbh}\right)$ & $1802(923)^{\mathrm{a}}$ & $820(114)^{\mathrm{a}}$ & $1924(256)^{\mathrm{a}}$ \\
Total basal area $\left(\mathrm{m}^{2} \mathrm{ha}^{-1}\right)$ & $10(0.73)^{\mathrm{a}}$ & $45(3.2)^{\mathrm{b}}$ & $50(3.2)^{\mathrm{b}}$ \\
Relative basal area (\%) (p: pines, b: broadleaf) & $91 \mathrm{p}, 9 \mathrm{~b}$ & $95 \mathrm{p}, 5 \mathrm{~b}$ & $80 \mathrm{p}, 20 \mathrm{~b}$ \\
\hline
\end{tabular}

cludes fragmented and partially decomposed organic matter that has lost its original structure. To measure the mass of the LL and DL sub-layers, we set up four radial lines $(12.62$ $\mathrm{m})$ originating at plot center, following each cardinal direction $(\mathrm{N}, \mathrm{E}, \mathrm{S}, \mathrm{W})$, and established four sampling points every $3 \mathrm{~m}$ (16 points plot $^{-1}$ ) where we measured the depth of LL and DL. To obtain LL and DL bulk density samples, we selected three random points in each plot and used a $30 \mathrm{~cm} \times 30 \mathrm{~cm}$ metal frame that was pushed into the organic layer to collect LL and DL samples (Ottmar and Andreu 2007 modified by Morfín et al. 2012).

We used a soil core ( $5 \mathrm{~cm}$ diameter) to obtain mineral soil samples from the top $10 \mathrm{~cm}$ of this layer, in eight points systematically selected from the 16 points used for LL and DL sampling. Four of the eight samples were used to determine soil bulk density.

\section{Sample Processing and Analyses}

Organic layer samples were oven dried at $60^{\circ} \mathrm{C}$ and weighed. Half-gram subsamples were ashed in a muffle furnace at $500^{\circ} \mathrm{C}$ for 4 $\mathrm{h}$ to determine inorganic content; data are reported on an ash-free, $60^{\circ} \mathrm{C}$ dry weight basis. The three subsamples were ground and passed through a 40 sieve, and then pooled into one composite sample per plot for chemical analyses.

Mineral soil samples were oven dried at $50^{\circ} \mathrm{C}$. Bulk density samples were weighed and the bulk density of the $<2 \mathrm{~mm}$ fraction was calculated for each plot; the eight subsamples were pooled into one composite sample per plot, which was then passed through a 100 sieve for all chemical analyses. Soil $\mathrm{pH}$ was determined with a potentiometer in water with a 1:2 (wt:vol) soil-solution ratio and in $\mathrm{Cl}_{2} \mathrm{Ca}$ 0.01 M solution in a 1:5 (wt:vol) soil-solution ratio. The sand and silt-clay fractions were separated under running water with a 320 sieve.

The LL, DL, and mineral soil samples were analyzed for total concentration of $\mathrm{C}, \mathrm{N}$, and $\mathrm{P}$ (TC, TN, and TP). The TC was determined by combustion and coulometric detection using an automated $\mathrm{CO}_{2}$ analyzer (UIC model CM5012, Joliet, Illinois, USA). The TN was determined after acid digestion by the macro-Kjendahl method and determined colorimetrically with a 3Bran-Luebbe auto analyzer (SPX, Norderstedt, Germany). The TP was obtained after acid digestion and reduction with ascorbic acid and determined colorimetrically in the same autoanalyzer used for TN.

\section{Statistical Analyses}

Mass $\left(\mathrm{Mg} \mathrm{ha}^{-1}\right)$ was calculated as the product of depth $(\mathrm{cm})$ and bulk density $\left(\mathrm{Mg} \mathrm{ha}^{-1}\right.$ $\left.\mathrm{cm}^{-1}\right)$. The TC, TN, and TP contents $\left(\mathrm{Mg} \mathrm{ha}^{-1}\right)$ of the organic and mineral soil layers were calculated as the product of $\mathrm{C}, \mathrm{N}$, and $\mathrm{P}$ concentration, bulk density, and thickness of the organic and mineral soil layers. Stands were considered treatment replicates. 
We tested the normality and homoscedasticity assumptions of all variables with the Kolmogorov-Smirnov and Levene tests, respectively. Data were log-transformed to meet assumptions when required (Zar 1999), although they are reported in their original scale of measurement. We used a nested analysis of variance to compare the effects of high-severity fires on depth; bulk density; mass; TC, TN, and $\mathrm{TP}$ concentrations and ratios; and $\mathrm{TC}, \mathrm{TN}$, and TP pools in the organic and mineral soil layers in the three stand ages $(8,28$ and 60). Stand age $(8,28$, and 60$)$ was the main fixed effect, and stands were the nested random effects within each stand age. We compared means with a Tukey test $(P=0.05)$; Pearson's correlation coefficient was used to estimate correlations between tree basal area and litter mass, and between tree basal area and soil $\mathrm{C}$ concentration. We used simple linear regression to relate soil $\mathrm{C}$ concentration to stand age.
All statistical analyses were carried out with SPSS version 15 (SPSS Inc., IBM, Armonk, New York, USA).

\section{RESULTS}

\section{Litter and Duff Mass}

The organic layer depth (LL + DL) differed significantly among ages $\left(F_{2.6}=55.85, P\right.$ $<0.001$ ), with $5.5 \mathrm{~cm}$ in the $8 \mathrm{yr}$ old stands, $16.4 \mathrm{~cm}$ in the $28 \mathrm{yr}$ old stands, and $14.5 \mathrm{~cm}$ in the $60 \mathrm{yr}$ old stands. The LL was deeper in the 28 yr old stands, while the DL did not show any differences between the $28 \mathrm{yr}$ old and 60 yr old stands (Table 2). Bulk density of LL and DL was lower in the 8 yr old than in the 28 yr old and 60 yr old stands (Table 2).

Total mass (LL + DL) in the 8 yr old stands represented $17 \%$ of that in the $28 \mathrm{yr}$ old and $60 \mathrm{yr}$ old stands (Figure 1). The LL mass was

Table 2. Physical and chemical properties of the litter and duff layers and the top mineral soil in 8 yr old, $28 \mathrm{yr}$ old, and $60 \mathrm{yr}$ old stands of Pinus douglasiana after high-severity fires in central-western Mexico. Values are average $(n=3)$ with the standard error in parentheses. Letters indicate significant differences between means $(P<0.05)$ with the post-hoc Tukey test.

\begin{tabular}{|c|c|c|c|c|c|c|c|c|c|}
\hline \multirow[b]{3}{*}{ Property } & \multirow{2}{*}{\multicolumn{3}{|c|}{$\begin{array}{c}\text { Litter layer (LL) } \\
\text { Stand age (yr) }\end{array}$}} & \multirow{2}{*}{\multicolumn{3}{|c|}{$\begin{array}{c}\text { Duff layer (DL) } \\
\text { Stand age (yr) }\end{array}$}} & \multirow{2}{*}{\multicolumn{3}{|c|}{$\begin{array}{c}\begin{array}{c}\text { Top mineral soil layer } \\
(0 \mathrm{~cm} \text { to } 10 \mathrm{~cm})\end{array} \\
\text { Stand age }(\mathrm{yr}) \\
\end{array}$}} \\
\hline & & & & & & & & & \\
\hline & 8 & 28 & 60 & 8 & 28 & 60 & 8 & 28 & 60 \\
\hline Depth $(\mathrm{cm})$ & $\begin{array}{l}3.6^{\mathrm{a}} \\
(0.5)\end{array}$ & $\begin{array}{l}8.2^{\mathrm{b}} \\
(0.5)\end{array}$ & $\begin{array}{l}7.1^{\mathrm{c}} \\
(0.6)\end{array}$ & $\begin{array}{l}1.9^{\mathrm{a}} \\
(0.4)\end{array}$ & $\begin{array}{l}8.2^{\mathrm{b}} \\
(0.5)\end{array}$ & $\begin{array}{l}7.4^{b} \\
(0.4)\end{array}$ & 10 & 10 & 10 \\
\hline Bulk density $\left(\mathrm{g} \mathrm{cm}^{-3}\right)$ & $\begin{array}{l}0.01^{\mathrm{a}} \\
(0.001)\end{array}$ & $\begin{array}{c}0.03^{\mathrm{b}} \\
(0.004)\end{array}$ & $\begin{array}{c}0.02^{\mathrm{b}} \\
(0.001)\end{array}$ & $\begin{array}{c}0.03^{\mathrm{a}} \\
(0.005)\end{array}$ & $\begin{array}{c}0.05^{\mathrm{b}} \\
(0.002)\end{array}$ & $\begin{array}{c}0.06^{\mathrm{b}} \\
(0.007)\end{array}$ & $\begin{array}{c}0.79 \\
(0.007)\end{array}$ & $\begin{array}{c}0.61 \\
(0.041)\end{array}$ & $\begin{array}{c}0.67 \\
(0.077)\end{array}$ \\
\hline $\mathrm{C}\left(\mathrm{mg} \mathrm{g}^{-1}\right)$ & $\begin{array}{l}471.5 \\
(7.1)\end{array}$ & $\begin{array}{c}478.7 \\
(2.8)\end{array}$ & $\begin{array}{c}472.4 \\
(3.5)\end{array}$ & $\begin{array}{l}444.1 \\
(11.8)\end{array}$ & $\begin{array}{c}459.5 \\
(1.0)\end{array}$ & $\begin{array}{c}454.4 \\
(9.3)\end{array}$ & $\begin{array}{l}57.4^{\mathrm{a}} \\
(4.3)\end{array}$ & $\begin{array}{l}72.1^{b} \\
(2.6)\end{array}$ & $\begin{array}{l}85^{\mathrm{c}} \\
(3.5)\end{array}$ \\
\hline $\mathrm{N}\left(\mathrm{mg} \mathrm{g}^{-1}\right)$ & $\begin{array}{l}5.5 \\
(0.8)\end{array}$ & $\begin{array}{l}5.7 \\
(0.2)\end{array}$ & $\begin{array}{c}6.1 \\
(0.3)\end{array}$ & $\begin{array}{l}7.5 \\
(0.2)\end{array}$ & $\begin{array}{l}9.1 \\
(0.8)\end{array}$ & $\begin{array}{c}8.7 \\
(0.3)\end{array}$ & $\begin{array}{l}3.7^{\mathrm{a}} \\
(0.1)\end{array}$ & $\begin{array}{l}4.0^{\mathrm{ab}} \\
(0.1)\end{array}$ & $\begin{array}{l}4.8^{b} \\
(0.3)\end{array}$ \\
\hline $\mathrm{P}\left(\mathrm{mg} \mathrm{g}^{-1}\right)$ & $\begin{array}{c}0.3 \\
(0.05)\end{array}$ & $\begin{array}{c}0.4 \\
(0.02)\end{array}$ & $\begin{array}{c}0.4 \\
(0.05)\end{array}$ & $\begin{array}{c}0.3 \\
(0.08)\end{array}$ & $\begin{array}{c}0.5 \\
(0.01)\end{array}$ & $\begin{array}{c}0.5 \\
(0.03)\end{array}$ & $\begin{array}{c}0.8 \\
(0.03)\end{array}$ & $\begin{array}{c}1.0 \\
(0.17)\end{array}$ & $\begin{array}{c}1.4 \\
(0.20)\end{array}$ \\
\hline $\mathrm{C}: \mathrm{N}$ & $\begin{array}{c}91 \\
(11)\end{array}$ & $\begin{array}{l}84 \\
(4)\end{array}$ & $\begin{array}{c}79 \\
(49)\end{array}$ & $\begin{array}{l}61 \\
(1)\end{array}$ & $\begin{array}{l}52 \\
(5)\end{array}$ & $\begin{array}{l}53 \\
(3)\end{array}$ & $\begin{array}{l}16 \\
(2)\end{array}$ & $\begin{array}{l}19 \\
(1)\end{array}$ & $\begin{array}{l}18 \\
(1)\end{array}$ \\
\hline $\mathrm{N}: \mathrm{P}$ & $\begin{array}{l}17 \\
(2)\end{array}$ & $\begin{array}{l}14 \\
(1)\end{array}$ & $\begin{array}{l}17 \\
(2)\end{array}$ & $\begin{array}{l}28 \\
(5)\end{array}$ & $\begin{array}{l}20 \\
(2)\end{array}$ & $\begin{array}{l}18 \\
(1)\end{array}$ & $\begin{array}{c}6 \\
(2)\end{array}$ & $\begin{array}{c}4 \\
(1)\end{array}$ & $\begin{array}{c}4 \\
(1)\end{array}$ \\
\hline $\mathrm{C}: \mathrm{P}$ & $\begin{array}{l}1553 \\
(280)\end{array}$ & $\begin{array}{l}1183 \\
(46)\end{array}$ & $\begin{array}{l}1304 \\
(188)\end{array}$ & $\begin{array}{l}1738 \\
(323)\end{array}$ & $\begin{array}{l}1030 \\
(25)\end{array}$ & $\begin{array}{l}958 \\
(72)\end{array}$ & $\begin{array}{l}118 \\
(60)\end{array}$ & $\begin{array}{l}74 \\
(8)\end{array}$ & $\begin{array}{c}65 \\
(13)\end{array}$ \\
\hline
\end{tabular}




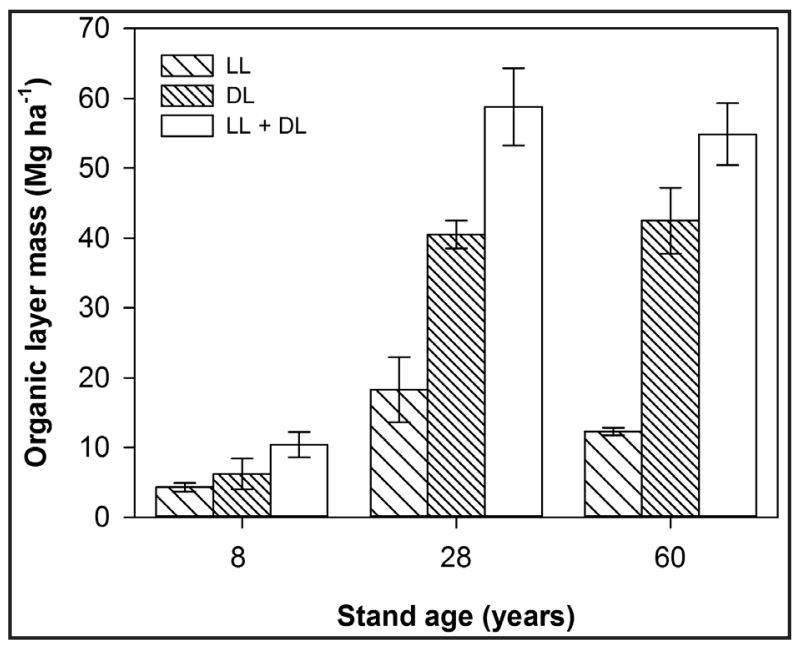

Figure 1. Total organic layer mass (LL + DL), litter layer mass (LL), and duff layer mass (DL) (mean \pm SE) in $8 \mathrm{yr}$ old, $28 \mathrm{yr}$ old, and $60 \mathrm{yr}$ old stands of Pinus douglasiana after high-severity fires in central-western Mexico.

4.2 $\mathrm{Mg} \mathrm{ha}^{-1}$ in the $8 \mathrm{yr}$ old stands, $18.3 \mathrm{Mg} \mathrm{ha}^{-1}$ in the $28 \mathrm{yr}$ old stands, and $12.3 \mathrm{Mg} \mathrm{ha}^{-1}$ in the $60 \mathrm{yr}$ old stands (Figure 1). The DL was 6.2 $\mathrm{Mg} \mathrm{ha}^{-1}$ in the $8 \mathrm{yr}$ old stands, representing $15 \%$ of that in the $28 \mathrm{yr}$ old and $60 \mathrm{yr}$ old stands (40.5 Mg ha-1 and $42.5 \mathrm{Mg} \mathrm{ha}^{-1}$, respectively; Figure 1). The masses of LL, DL, and total organic layer (LL $+\mathrm{DF})$ were positively related to the basal area of the trees $\left(\mathrm{R}^{2}=0.35\right.$, $P \leq 0.001 ; \mathrm{R}^{2}=0.64, P \leq 0.001 ; \mathrm{R}^{2}=0.64, P \leq$ 0.001 , respectively).

\section{$C, N$, and $P$ Contents of the Organic Layer}

The TC, TN, and TP concentrations in the LL and DL were not significantly different among the three stand ages (Table 2). Average $\mathrm{TC}, \mathrm{TN}$, and TP concentrations in the LL were $474 \pm 2 \mathrm{mg} \mathrm{g}^{-1}, 5.8 \pm 0.2 \mathrm{mg} \mathrm{g}^{-1}$, and $0.38 \pm 0.02$ $\mathrm{mg} \mathrm{g}^{-1}$, respectively. Average concentrations in the DL were $452 \pm 5 \mathrm{mg} \mathrm{g}^{-1}, 8.4 \pm 0.5 \mathrm{mg} \mathrm{g}^{-1}$, and $0.43 \pm 0.05 \mathrm{mg} \mathrm{g}^{-1}$, respectively. The $\mathrm{C}: \mathrm{N}$, $\mathrm{N}: \mathrm{P}$, and $\mathrm{C}: \mathrm{P}$ ratios in LL were relatively constant among the three stand ages. The $C: N$, $\mathrm{N}: \mathrm{P}$, and $\mathrm{C}: \mathrm{P}$ ratios in DL were not significantly different among the three ages (Table 2).
The TC, TN, and TP contents in both LL and DL were different among ages (Table 3 ). In the LL, the 8 yr old and 28 yr old stands had the lowest and the highest TC, TN, and TP contents, respectively (Figure 2). In the DL, the $8 \mathrm{yr}$ old stands had lower TC, TN, and TP contents, but these did not change in the $28 \mathrm{yr}$ old and $60 \mathrm{yr}$ old stands (Figure 2).

Table 3. Nested analysis of variance ( $F$ and $P$ ) with stand nested within stand age for total $\mathrm{C}, \mathrm{N}$, and $\mathrm{P}\left(\mathrm{Mg} \mathrm{ha}^{-1}\right)$ in the organic layer and the top mineral soil in $8 \mathrm{yr}$ old, $28 \mathrm{yr}$ old and $60 \mathrm{yr}$ old stands of Pinus douglasiana after high-severity fires in central-western Mexico. Stand age is the fixed effects factor; stand is the nested stand effect, within stand age, as random effects factor.

\begin{tabular}{|c|c|c|c|c|}
\hline \multirow[b]{3}{*}{ Parameter } & \multicolumn{4}{|c|}{ Variation source } \\
\hline & \multicolumn{2}{|c|}{ Stand age } & \multicolumn{2}{|c|}{$\begin{array}{c}\text { Stand nested } \\
\text { within stand age }\end{array}$} \\
\hline & $F$ & $P$ & $F$ & $\boldsymbol{P}$ \\
\hline & \multicolumn{4}{|c|}{ Litter layer (LL) } \\
\hline $\mathrm{C}$ & 6.53 & 0.031 & 9.530 & $\leq 0.001$ \\
\hline $\mathrm{N}$ & 7.24 & 0.025 & 10.49 & $\leq 0.001$ \\
\hline \multirow[t]{2}{*}{$\mathrm{P}$} & 8.39 & 0.018 & 15.55 & $\leq 0.001$ \\
\hline & \multicolumn{4}{|c|}{ Duff layer (DL) } \\
\hline $\mathrm{C}$ & 31.3 & 0.001 & 0.962 & 0.477 \\
\hline $\mathrm{N}$ & 42.7 & $\leq 0.001$ & 0.477 & 0.816 \\
\hline \multirow[t]{2}{*}{$\mathrm{P}$} & 24.6 & 0.001 & 0.631 & 0.704 \\
\hline & \multicolumn{4}{|c|}{ Total organic layer $(\mathrm{LL}+\mathrm{DL})$} \\
\hline $\mathrm{C}$ & 34.9 & $\leq 0.001$ & 1.240 & 0.334 \\
\hline $\mathrm{N}$ & 38.5 & $\leq 0.001$ & 0.762 & 0.609 \\
\hline \multirow[t]{2}{*}{$\mathrm{P}$} & 30.1 & 0.001 & 0.802 & 0.581 \\
\hline & \multicolumn{4}{|c|}{ Top mineral soil $(0 \mathrm{~cm}$ to $10 \mathrm{~cm})$} \\
\hline $\mathrm{C}$ & 4.71 & 0.059 & 1.917 & 0.133 \\
\hline $\mathrm{N}$ & 2.43 & 0.168 & 1.966 & 0.124 \\
\hline $\mathrm{P}$ & 1.07 & 0.400 & 14.33 & $\leq 0.001$ \\
\hline
\end{tabular}

Top Mineral Soil Layer

The soil mass was formed of silt and clay particles $(74 \%$ to $78 \%)$ in the three stand ages 


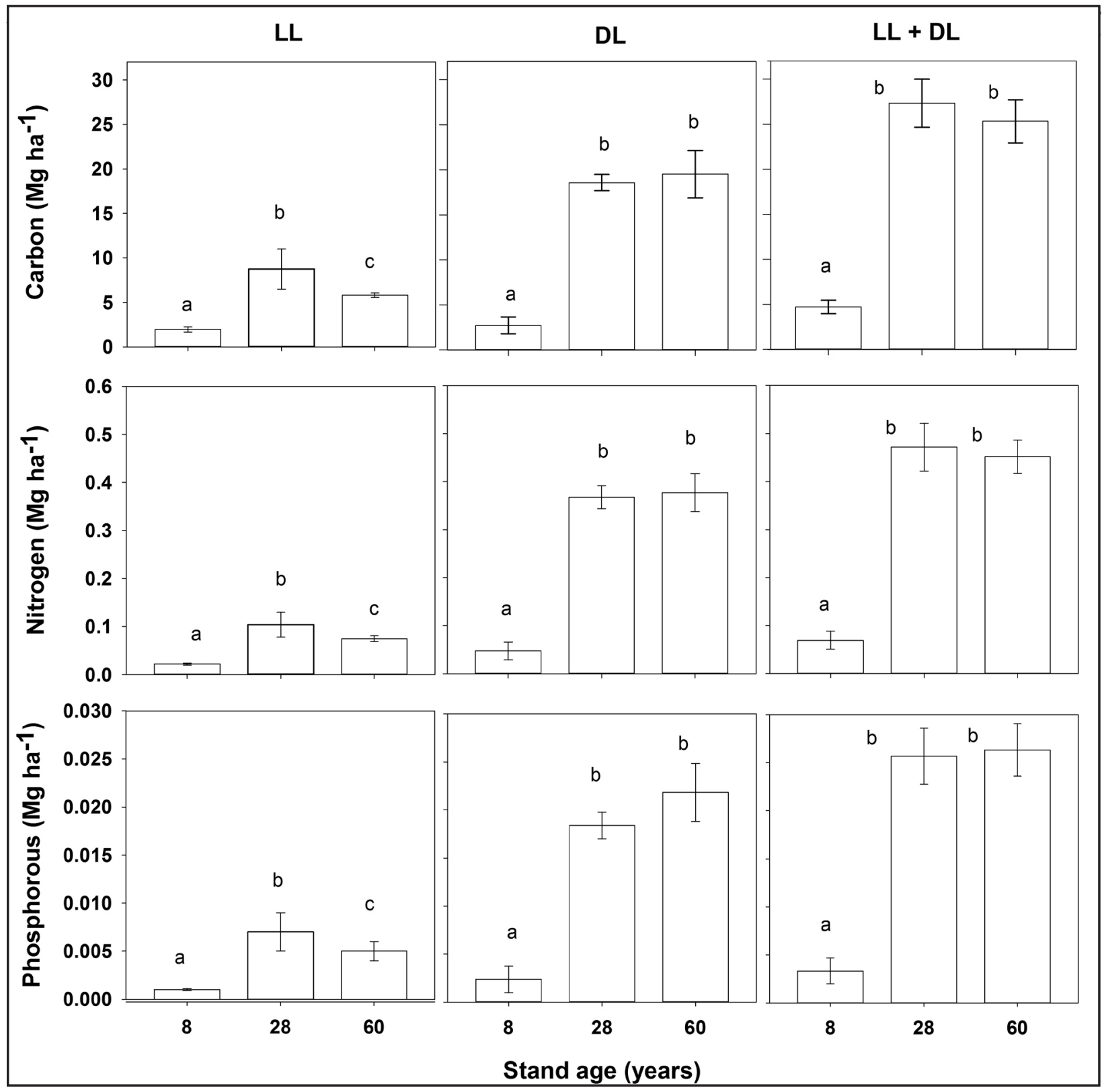

Figure 2. Contents of total C, N, and $\mathrm{P}$ in the litter layer (LL), duff layer (DL), and total organic layer (LL + DL) (mean \pm SE) in $8 \mathrm{yr}$ old, $28 \mathrm{yr}$ old, and $60 \mathrm{yr}$ old stands of Pinus douglasiana after high-severity fires in central-western Mexico. Bars with different letters show significant differences between means $(P$ $<0.05)$ with the post-hoc Tukey test.

$(8,28$, and 60$)$; soil bulk density was similar among these (Table 2). The $\mathrm{pH}$ was moderately acidic (5.3 to 5.6); there were no significant differences in $\mathrm{pH}$ among the three stand ages.

\section{Soil C, N, and P Contents}

Soil C concentration increased with stand age, being higher in the $60 \mathrm{yr}$ old stands (Table $2)$. The regression between $C$ concentration and stand age was significant $\left(\beta=0.5181, \mathrm{R}^{2}=\right.$
$0.56, P \leq 0.001)$; tree basal area was positively correlated with soil $\mathrm{C}$ concentration $\left(\mathrm{R}^{2}=\right.$ $0.36, P \leq 0.001)$.

Soil $\mathrm{N}$ concentration was lower in the $8 \mathrm{yr}$ old than the $60 \mathrm{yr}$ old stands; while the concentration in the 28 yr old stands did not differ from the $8 \mathrm{yr}$ old and $60 \mathrm{yr}$ old stands. Soil $\mathrm{P}$ concentrations did not differ among the three stand ages. The $\mathrm{C}: \mathrm{N}, \mathrm{N}: \mathrm{P}$, and $\mathrm{C}: \mathrm{P}$ ratios were relatively constant among the three ages (Table 2). 
Soil C contents were not different among ages (Figure 3), but we observed a trend of

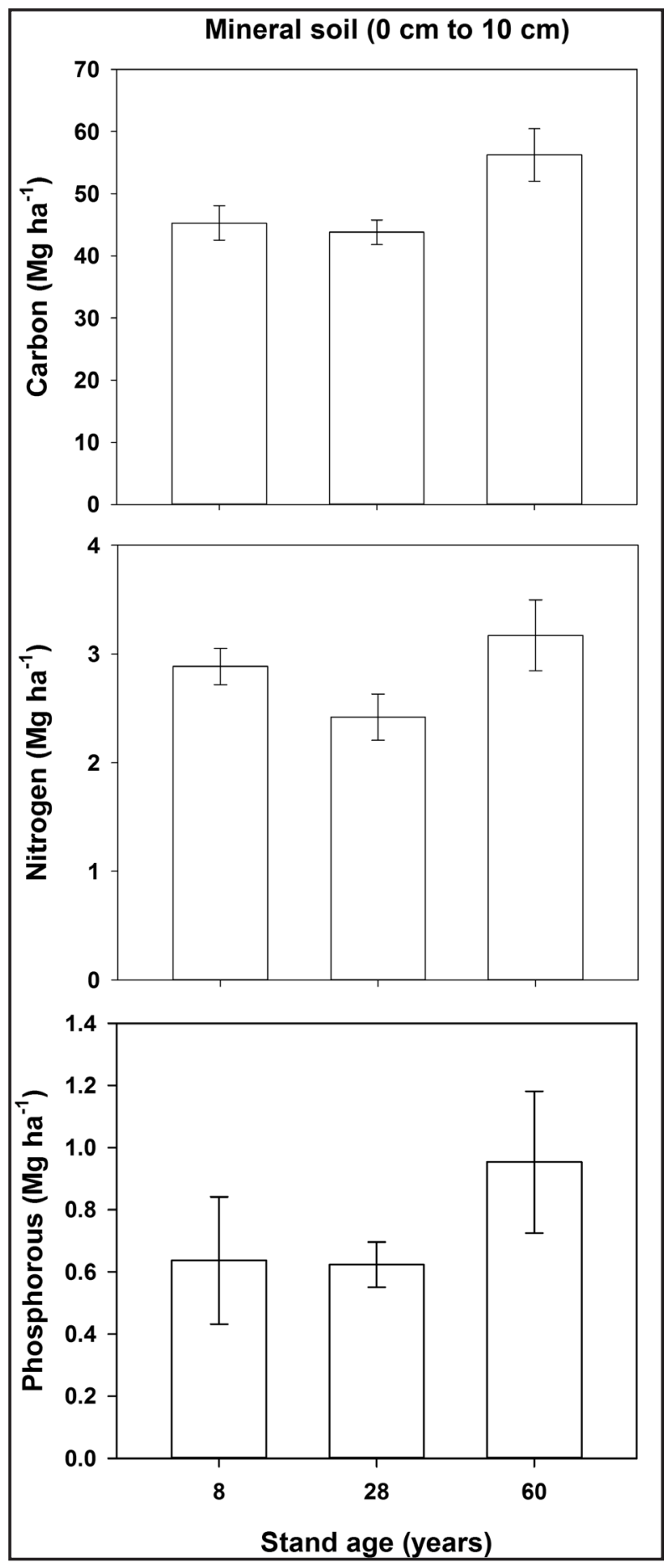

Figure 3. Contents of total C, N, and $\mathrm{P}$ in the top mineral soil (mean $\pm \mathrm{SE}$ ) in $8 \mathrm{yr}$ old, $28 \mathrm{yr}$ old, and $60 \mathrm{yr}$ old stands of Pinus douglasiana after high-severity fires in central-western Mexico. higher values in the mature stands with 56.24 $\mathrm{Mg} \mathrm{ha}^{-1}\left(F_{2,6}=4.7 P=0.059\right)$. The $\mathrm{N}$ and $\mathrm{P}$ contents were not significant among the three stand ages. The nested effect of the site on soil $\mathrm{P}$ content was significant (Table 3 ).

\section{DISCUSSION}

\section{Organic Layer $C, N$, and P Contents}

Concentrations $\left(\mathrm{mg} \mathrm{g}^{-1}\right)$ of $\mathrm{C}, \mathrm{N}$, and $\mathrm{P}$ in LL and DL were similar after the severe fire in the study sites, which suggests that the type of litter inputs to the system did not change across these successional stages. This was expected, as Pinus douglasiana represents 70\% or more of tree basal area in the study sites, and the organic layer was formed mostly of organic compounds produced by this species. Similar results were found by MacKenzie et al. (2004) in a chronosequence of low elevation, second growth Pinus ponderosa-Pseudotsuga menziesii (Mirb.) Franco forest in western Montana, USA, and by Switzer et al. (1979) in a secondary succession of pine forest in eastern Mississippi, USA.

The low $\mathrm{C}, \mathrm{N}$, and $\mathrm{P}$ contents in the organic layer in the $8 \mathrm{yr}$ old stands suggest that the high-severity fire eliminated most of the organic layer mass, and that its accumulation is slower in the first years following the disturbance. Several studies have reported that organic layer combustion during high-severity fires causes substantial losses of $\mathrm{C}, \mathrm{N}$, and $\mathrm{P}$ soil contents (for instance, see Baird et al. 1999, Murphy et al. 2006, Neary and Overby 2006). While our study did not evaluate the organic layer loss during fire events, preliminary observations indicate that high-severity fires in LJRS have drastic effects on the organic layer mass, reducing it by $80 \%$ to $100 \%$ (E.J. Jardel, Universidad de Guadalajara, Autlán de Navarro, Mexico, unpublished data).

Tree basal area in the $8 \mathrm{yr}$ old stands was four times lower than in the $28 \mathrm{yr}$ old and 60 yr old stands - an expected effect of high-se- 
verity fires, which strongly alters the forest structure (MacKenzie et al. 2004, Kashian et al. 2006). In our study sites, reduction of tree mass also decreased tree productivity, depleting organic matter inputs to the system. Additionally, forest canopy opening promotes litter decomposition by raising organic layer temperatures (Smithwick et al. 2005, Nave et al. 2011). The positive relationship between organic layer mass and tree basal area suggests that leaf litter production is lower in the youngest sites ( $8 \mathrm{yr}$ old stands), and that the input of new organic matter to the soil is not at an equilibrium between litterfall production and litter decomposition, which has been confirmed in previous studies (Buschiazzo et al. 2004, Hu et al. 2013).

In our study sites, 28 years after high-severity fire, forest floor mass was similar to that of $60 \mathrm{yr}$ old stands $\left(59 \mathrm{Mg} \mathrm{ha}^{-1}\right.$ and $55 \mathrm{Mg} \mathrm{ha}^{-1}$, respectively), which suggests that litterfall production and organic layer decomposition are at equilibrium approximately 28 years following a high-severity fire. The mass of the organic layer determined through this study is greater than values reported for several pine forests of the USA (25 Mg ha-1 and $28 \mathrm{Mg} \mathrm{ha}^{-1}$ 30 years and 50 years after high-severity fires, respectively), but similar to those reported for $50 \mathrm{yr}$ old mixed conifer and broadleaf forests in North America (60 $\mathrm{Mg} \mathrm{ha}^{-1}$ ) (Smith and Heath 2002).

\section{Top Mineral Soil C, N, and P Contents}

While it has been reported that high-severity fires can strongly alter the properties of mineral soils (Neary et al. 1999, Certini 2005), our results show that, 8 years after a high-severity fire, bulk density; $\mathrm{pH}$; soil $\mathrm{P}$ concentration; $\mathrm{C}: \mathrm{N}, \mathrm{N}: \mathrm{P}$, and $\mathrm{C}: \mathrm{P}$ ratios; and soil $\mathrm{C}, \mathrm{N}$ and $\mathrm{P}$ contents were similar to those of $60 \mathrm{yr}$ old stands. This suggests that the effect of high-severity fires is temporary and could even decrease shortly after fire, as has been shown by previous studies (Johnson and Curtis 2001,
Wan et al. 2001, LeDuc and Rothstein 2007, Nave et al. 2011, Chen and Shrestha 2012).

Soil $\mathrm{C}$ and $\mathrm{N}$ concentrations in the $8 \mathrm{yr}$ old stands were lower than in the $60 \mathrm{yr}$ old stands, which is consistent with previous studies in temperate forests worldwide that report reduced soil $\mathrm{C}$ and $\mathrm{N}$ concentrations due to volatilization during high-severity fires (Kutiel and Naveh 1987, Fernández et al. 1997, Baird et al. 1999, Murphy et al. 2006, Rovira et al. 2012). However, recovery times can be different. Alauzis et al. (2004) found that, four years after a fire in Nothofagus pumilio forests, $\mathrm{C}$ and $\mathrm{N}$ soil concentrations were $52 \%$ and $22 \%$, respectively, lower than in control sites. Similarly, LeDuc and Rothstein (2007) found that soil $\mathrm{N}$ concentration was $36 \%$ lower six years after a severe fire than in control stands in Pinus banksiana-dominated forests.

We detected a positive and statistically significant relationship between tree basal area and soil $\mathrm{C}$ concentration, in which the youngest sites had a lower tree basal area and soil $\mathrm{C}$ concentration than the older stands ( $28 \mathrm{yr}$ old and $60 \mathrm{yr}$ old stands), which has also been reported by other studies ( $\mathrm{Hu}$ et al. 2013, García-Oliva et al. 2014). These results can be explained by the high levels of tree mortality that occur during high-severity forest fires, depleting litter inputs to the mineral soil. Other studies have shown that soil $\mathrm{C}$ and $\mathrm{N}$ recuperation will depend on increased tree production (Brown and Lugo 1990, Richter et al. 1999).

Soil textures dominated by fine particles increase the amount of $\mathrm{C}$ stored in the soil, as clays form stable compounds with organic and metal molecules, favoring $\mathrm{C}$ stabilization in the soil (Six et al. 2002, Lützow et al. 2006). Since soils in the study area are dominated by fine particles, we suggest that they play a key role in SOC accumulation, as has been reported for other pine forests in volcanic soils in Mexico (Peña-Ramírez et al. 2009). The SOC yearly accumulation rate $\left(0.52 \mathrm{mg} \mathrm{C} \mathrm{g}^{-1}\right)$, shown in the regression between SOC concen- 
tration and stand age, reaches concentrations of $85 \mathrm{mg} \mathrm{C} \mathrm{g}^{-1} 60$ years after a fire. This value is within the range reported by other authors for conifer forests on volcanic soils in Mexico: $56 \mathrm{mg} \mathrm{g}^{-1}$ to $89 \mathrm{mg} \mathrm{g}^{-1}$ in Pinus montezumae Lamb. forests (Peña-Ramírez et al. 2009) and $73 \mathrm{mg} \mathrm{g}^{-1}$ to $89 \mathrm{mg} \mathrm{g}^{-1}$ in pine-oak forests in southeastern Mexico (Mendoza-Vega et al. 2003). These results suggest that, in the study area, SOC concentrations reach higher values in mature Pinus douglasiana forests without severe fires for at least 60 years.

Post-fire recovery of soil organic matter and nutrient content begins with vegetation regeneration (Certini 2005). Pinus douglasiana forests in LJRS have a high capacity to regenerate following high-severity fires (Jardel 1991, Llamas-Casillas 2009). Our results suggest a rapid recovery of $\mathrm{C}, \mathrm{N}$, and $\mathrm{P}$, which may be a result of the high metabolic rate (i.e., high primary productivity and high transformation rate of soil organic matter) of forest ecosystems in tropical latitudes. In sub-humid temperate climates with summer rains, the precipitation corresponds with the growing season, and higher precipitation is associated with increased vegetation growth, organic $\mathrm{C}$ inputs, and SOC accumulation.

In the context of increased frequency and severity of wildfire resulting from human-derived fire suppression and climate change, there is a threat of higher soil carbon and nutrient losses, which will reduce forest productivity (Covington and Moore 1992, Georgiadis 2011). Forest managers must consider these potential threats when developing fire and forest management plans, to reduce vulnerability or to enhance forest recovery.

\section{ACKNOWLEDGEMENTS}

This study was funded by the Consejo Estatal de Ciencia y Tecnología of the State of Jalisco through the grant Estructura, diversidad y reservorios de carbono de bosques de cañadas en el Pacifico Mexicano (PS-2009-664). The first author received financial support from Consejo Nacional de Ciencia y Tecnología (scholarship number 272059/222300). R. Velázquez-Durán helped with chemical analyses at the Laboratorio de Biogeoquímica de Suelos, Instituto de Investigaciones en Ecosistemas y Sustentabilidad, Universidad Nacional Autónoma de México. We thank Dr. C. Cortés Montaño for comments on previous drafts of this manuscript.

\section{LITERATURE CITED}

Agee, J.K. 1993. Fire ecology of Pacific Northwest forests. Island Press, Washington, D.C., USA.

Alauzis, M.V., M.J. Mazzarino, E. Raffaele, and L. Roselli. 2004. Wildfires in NW Patagonia: long-term effects on a Nothofagus forest soil. Forest Ecology and Management 192: 131142. doi: 10.1016/j.foreco.2003.11.014

Allen, D.E., M.J. Pringle, K.L. Page, and R.C. Dalal. 2010. A review of sampling designs for the measurement of soil organic carbon in Australian grazing lands. The Rangeland Journal 32: 227-246. doi: 10.1071/RJ09043

Alvarado-Celestino, E., J.E. Morfín-Ríos, E.J. Jardel-Pelaéz, R.E. Vihnanek, D.K. Wright, J.M. Michel-Fuentes, C.S. Wright, R.D. Ottmar, D.V. Sandberg, and A. Nájera-Díaz. 2008. Fotoseries para la cuantificación de combustibles forestales de México: bosques montanos subtropicales de la Sierra Madre del Sur y bosques templados y matorral submontano del norte de la Sierra Madre Oriental. Pacific Wildland Fire Sciences Laboratory Special Publication No. 1, University of Washington, College of Forest Resources, Seattle, Washington, USA. [In Spanish.] 
Badia, D., C. Martí, A.J. Aguirre, J.M. Aznar, J.A. González-Pérez, J.M. De la Rosa, J. León, P. Ibarra, and T. Echeverría. 2014. Wildfire effects on nutrients and organic carbon of a Rendzic Phaeozem in NE Spain: changes at cm-scale topsoil. Catena 113: 267-275. doi: 10.1016/j. catena.2013.08.002

Baird, M., D. Zabowski, and R.L. Everett. 1999. Wildfire effects on carbon and nitrogen in inland coniferous forests. Plant and Soil 209: 233-243. doi: 10.1023/A:1004602408717

Balcázar, O.E. 2011. Patrones geoecológicos de incendios forestales en la Reserva de la Biosfera Sierra de Manantlán. Thesis, Universidad de Guadalajara, México. [In Spanish.]

Bento-Goncalves, A., A. Vieira, X. Úbeda, and D. Martin. 2012. Fire and soils: key concepts and recent advances. Geoderma 191:3-13. doi: 10.1016/j.geoderma.2012.01.004

Boerner, R.E.J. 1982. Fire and nutrient cycling in temperate ecosystems. BioScience 32: 187192. doi: $10.2307 / 1308941$

Brown, S., and A.E. Lugo. 1990. Effects of forest clearing and succession on the carbon and nitrogen content of soils in Puerto Rico and US Virgin Islands. Plant and Soil 124: 53-64. doi: 10.1007/BF00010931

Buschiazzo, D.E., H.D. Estelrich, S.B. Aimar, E. Viglizzo, and F.J. Babinec. 2004. Soil texture and tree coverage influence on organic matter. Journal of Range Management 57: 511-516. doi: $10.2307 / 4003981$

Carter, M.C., and C.D. Foster. 2004. Prescribed burning and productivity in southern pine forests: a review. Forest Ecology and Management 191: 93-109. doi: 10.1016/j.foreco. 2003.11.006

Cerano-Paredes, J., J. Villanueva-Díaz, R. Cervantes-Martínez, P. Fulé, L. Yocom, G. Esquivel-Arriaga, and E. Jardel-Peláez. 2015. Historia de incendios en un bosque de pino de la sierra de Manantlán, Jalisco, México. Bosque 36: 41-52. [In Spanish.]

Certini, G. 2005. Effects of fire on properties of forest soils: a review. Oecologia 143: 1-10. doi: $10.1007 / \mathrm{s} 00442-004-1788-8$

Chen, H.Y.H., and B.M. Shrestha. 2012. Stand age, fire and clearcutting affect soil organic carbon and aggregation of mineral soils in boreal forests. Soil Biology and Biochemistry 50: 149-157. doi: 10.1016/j.soilbio.2012.03.014

Covaleda, S.O. 2008. Influencia de diferentes impactos antrópicos en la dinámica del carbono y la fertilidad de suelos volcánicos mexicanos, implicaciones sobre el secuestro de carbono. Dissertation, Valladolid University, Palencia, Spain. [In Spanish.]

Covington, W.W., and M.M. Moore. 1992. Restoration of presettlement tree densities and natural fire regimes in ponderosa pine ecosystems. Bulletin of the Ecological Society of America 73: $142-148$.

DeBano, L.F., and C.E. Conrad. 1978. The effect of fire on nutrients in a chaparral ecosystem. Ecology 59: 489-497. doi: 10.2307/1936579

Duran, J., A. Rodríguez, J.M. Fernández-Palacios, and A. Gallardo. 2010. Long-term decrease of organic and inorganic nitrogen concentrations due to pine forest wildfire. Annals of Forest Science 67(2): 207. doi: 10.1051/forest/2009100

Fernández, I., A. Cabaneiro, and T. Carballas. 1997. Organic matter changes immediately after a wildfire in an Atlantic forest soil and comparison with laboratory soil heating. Soil Biology and Biochemistry 29: 1-11. doi: 10.1016/S0038-0717(96)00289-1

Fulé, P.Z., and W.W. Covington. 1997. Fire regimes and forest structure in the Sierra Madre, Occidental, Durango, Mexico. Acta Botanica Mexicana 41: 43-79. 
García-Oliva, F., and V.J. Jaramillo. 2011. Impact of anthropogenic transformation of seasonally dry tropical forest on ecosystem biogeochemical process. Pages 159-172 in: R. Dirzo, H.S. Young, H.A. Mooney, and G. Ceballos, editors. Seasonally dry tropical forests: ecology and conservation. Island Press, Washington, D.C., USA. doi: 10.5822/978-1-61091-021-7_10

García-Oliva, F., S.O. Covadela, J.F. Gallardo, C. Prat, R. Velázquez-Durán, and J.D. Etchevers. 2014. Firewood extraction affects carbon pools and nutrients in remnant fragments of temperate forests at the Mexican Transvolcanic Belt. Bosque 35: 311-324. doi: 10.4067/ S0717-92002014000300006

Georgiadis, P. 2011. Accumulation of carbon and nitrogen in Swedish forest soils over stand age. Thesis, Swedish University of Agricultural Sciences, Uppsala, Sweden.

Giardina, C.P., R.L. Sanford, and I.C. Dockersmith. 2000. Changes in soil phosphorus and nitrogen during slash-and-burn clearing of a dry tropical forest. Soil Science Society of America Journal 64: 399-405. doi: 10.2136/sssaj2000.641399x

Grove, T.S., A.M. O'Connell, and G.M. Dimmock. 1986. Nutrient changes in surface soils after an intense fire in jarrah (Eucalyptus marginata Donn ex Sm.) forest. Australian Journal of Ecology 11: 303-317. doi: 10.1111/j.1442-9993.1986.tb01400.x

Guénon, R., M. Vennetier, N. Dupuy, S. Roussos, A. Pailler, and R. Gros. 2013. Trends in recovery of Mediterranean soil chemical properties and microbial activities after infrequent and frequent wildfires. Land Degradation and Development 24: 115-128. doi: 10.1002/ldr.1109

Gurmesa, G.A., I.K. Schmidt, P. Gundersen, and L. Vesterdal. 2013. Soil carbon accumulation and nitrogen retention traits of four tree species grown in common gardens. Forest Ecology and Management 309: 47-57. doi: 10.1016/j.foreco.2013.02.015

Hu, Y.L., D.H. Zeng, S.X. Chang, and R. Mao. 2013. Dynamics of soil and root C stocks following afforestation of croplands with poplars in a semi-arid region in northeast China. Plant and Soil 368: 619-627. doi: 10.1007/s11104-012-1539-2

Jardel, E.J. 1991. Perturbaciones naturales y antropogénicas y su influencia en la dinámica sucesional de los bosques de Las Joyas, Sierra de Manantlán, Jalisco. Tiempos de Ciencia 22: 9-26. [In Spanish.]

Jardel, E.J., E. Alvarado, J.E. Morfín-Ríos, F. Castillo-Navarro, and J.G. Flores-Garnica. 2009. Regímenes de incendios en ecosistemas forestales de México. Pages 73-100 in: J.G. Flores-Garnica, editor. Impacto ambiental de incendios forestales. Mundi-Prensa, Instituto Nacional de Investigaciones Forestales, Agrícolas y Pecuarias y Colegio de Postgraduados, Distrito Federal, Mexico. [In Spanish.]

Jardel, E.J., L.M. Martínez-Rivera, J.M. Ramírez-Romero, and D. Partida-Lara. 2004b. Condiciones físico-geográficas de las Joyas y sus alrededores. Pages 179-203 in: R. Cuevas-Guzmán and E.J. Jardel, editors. Flora y vegetación de la Estación Científica Las Joyas. Universidad de Guadalajara, Mexico. [In Spanish.]

Jardel, E.J., A.L. Santiago-Pérez, C. Cortés-Montaño, and F. Castillo-Navarro. 2004a. Sucesión y dinámica de rodales. Pages 179-203 in: G.R. Cuevas and P.E.J. Jardel, editors. Flora y vegetación de la Estación Científica Las Joyas. Universidad de Guadalajara, Mexico. [In Spanish.]

Johnson, D.W., and P.S. Curtis. 2001. Effects of forest management on soil C and N storage: meta analysis. Forest Ecology and Management 140: 227-238. doi: 10.1016/S0378-1127 (00)00282-6 
Johnson, D.W., R.B. Susfalk, T.G. Caldwell, J.D. Murphy, W.W. Miller, and R.F. Walker. 2004. Fire effects on carbon and nitrogen budgets in forest. Water, Air and Soil Pollution 4: 263275. doi: 10.1023/B:WAFO.0000028359.17442.d1

Kashian, D.M., W.H. Romme, D.B. Tinker, M.G. Turner, and M.G. Ryan. 2006. Carbon storage on landscapes with stand-replacing fires. BioScience 56: 598-606. doi: 10.1641/0006-3568(2006)56[598:CSOLWS]2.0.CO;2

Kutiel, P., and Z. Naveh. 1987. The effect of fire on nutrients in a pine forest soil. Plant and Soil 104: 269-274. doi: 10.1007/BF02372541

LeDuc, S.D., and D.E. Rothstein. 2007. Initial recovery of soil carbon and nitrogen pools and dynamics following disturbance in jack pine forests: a comparison of wildfire and clearcut harvesting. Soil Biology and Biochemistry 39: 2865-2876. doi: 10.1016/j.soilbio. 2007.05.029

Llamas-Casillas, P. 2009. Sucesión en bosques de pino-encino afectados por incendios severos en la Sierra de Manantlán. Undergraduate thesis, Universidad de Guadalajara, Mexico. [In Spanish.]

Llamas-Casillas, P. 2013. Régimen histórico de incendios en bosques de coníferas del sur occidente de Jalisco. Thesis, Universidad de Guadalajara, Mexico. [In Spanish.]

Lützow, M.V., I. Kögel-Knabner, K. Ekschmitt, E. Matzner, G. Guggenberger, B. Marschner, and H. Flessa. 2006. Stabilization of organic matter in temperate soils: mechanisms and their relevance under different soil conditions - a review. European Journal of Soil Science 57: 426445. doi: 10.1111/j.1365-2389.2006.00809.x

MacKenzie, D.M., T.H. DeLuca, and A. Sala. 2004. Forest structure and organic matter analysis along a fire chronosequence in the low elevation forests of western Montana. Forest Ecology and Management 203: 331-343. doi: 10.1016/j.foreco.2004.08.003

Martín, A., M. Díaz-Raviña, and T. Carballas. 2012. Short and medium term evolution of soil properties in Atlantic forest ecosystems affected by wildfires. Land Degradation and Development 23: 427-439. doi: 10.1002/1dr.1078

Martínez, R.L.M., I.R. Delgado, and R.I. Flores. 1993. Suelos de la Estación Científica Las Joyas de la Reserva de la Biosfera Sierra de Manantlán, Jalisco. Agrociencia, Serie Agua-Suelo-Clima 4: 103-115. [In Spanish.]

Mendoza-Vega, J., E. Karltun, and M. Olsson. 2003. Estimations of amounts of soil organic carbon and fine root carbon in land use and land cover classes, and soil types of Chiapas highlands, Mexico. Forest Ecology and Management 177: 191-206. doi: 10.1016/S0378-1127 (02)00439-5

Morfín, R.J.E., P.E.J. Jardel, C.E. Alvarado, and F.J.M. Michel. 2012. Caracterización y cuantificación de combustibles forestales. Comisión Nacional Forestal, Universidad de Guadalajara, Jalisco, Mexico. [In Spanish.]

Murphy, J.D., D.W. Johnson, W.W. Miller, R.F. Walker, E.F. Carroll, and R.R. Blank. 2006. Wildfire effects on soil nutrients and leaching in a Tahoe Basin watershed. Journal of Environmental Quality 35: 479-489. doi: 10.2134/jeq2005.0144

Nave, L.E., E.D. Vance, C.W. Swanston, and P.S. Curtis. 2011. Fire effects on temperate forest soil C and N storage. Ecological Applications 21: 1189-1201. doi: 10.1890/10-0660.1

Neary, D.G., C.C. Klopatek, L.F. DeBano, and P.F. Ffolliott. 1999. Fire effects on belowground sustainability: a review and synthesis. Forest Ecology and Management 122: 51-71. doi: 10.1016/S0378-1127(99)00032-8 
Neary, D.G., and S.T. Overby. 2006. Wildfire and post-fire erosion impacts on forest ecosystem carbon and nitrogen: an analysis. Forest Ecology and Management 234S: S162. doi: 10.1016/j.foreco.2006.08.213

Neary, D.G., K.C. Ryan, and L.F. DeBano. 2005. (Revised 2008.) Wildland fire in ecosystems: effects of fire on soils and water. USDA Forest Service General Technical Report RMRSGTR-42-vol.4, Rocky Mountain Research Station, Fort Collins, Colorado, USA.

Ottmar, R.D., and A. Andreu. 2007. Litter and duff bulk densities in the southern United States. USDA Forest Service, Joint Fire Science Program Project \#04-2-1-49, Pacific Northwest Research Station and Pacific Wildland Fire Sciences Laboratory, Seattle, Washington, USA.

Overby, S., S. Hart, and D. Neary. 2003. Impacts of natural disturbance on soil carbon dynamics in forest ecosystems. Pages 159-172 in: J.M. Kimble, L.S. Heath, R. Birdsey, and R. Lal, editors. The potential of US forest soils to sequester carbon and mitigate the greenhouse effect. CRC Press, Boca Raton, Florida, USA.

Peña-Ramírez, V.M., L. Vázquez-Selem, and C. Siebe. 2009. Soil organic carbon stocks and forest productivity in volcanic ash soils of different age (1835-30,500 years B.P.) in Mexico. Geoderma 149: 224-234. doi: 10.1016/j.geoderma.2008.11.038

Post, W.M., and K.C. Kwon. 2000. Soil carbon sequestration and land-use change: processes and potential. Global Change Biology 6: 317-328. doi: 10.1046/j.1365-2486.2000.00308.x

Powers, E.M., J.D. Marshall, J. Zhang, and L. Wei. 2013. Post-fire management regimes affect carbon sequestration and storage in a Sierra Nevada mixed conifer forest. Forest Ecology and Management 291: 268-277. doi: 10.1016/j.foreco.2012.07.038

Richter, D., D. Markewitz, S.E. Trumbore, and C.G. Wells. 1999. Rapid accumulation and turnover of soil carbon in a re-establishing forest. Nature 400: 56-58. doi: 10.1038/21867

Rodríguez-Trejo, D.A., P.A. Martínez-Hernández, H. Ortiz-Contla, M.R. Chavarría-Sánchez, and F. Hernández-Santiago. 2011. The present status of fire ecology, traditional use of fire, and fire management in Mexico and Central America. Fire Ecology 7(1): 40-56. doi: 10.4996/ fireecology.0701040

Rovira, P., J. Romanyá, and B. Duguy. 2012. Long-term effects of wildfires on the biochemical quality of soil organic matter: a study on Mediterranean shrublands. Geoderma 179-180: 9-19. doi: 10.1016/j.geoderma.2012.02.011

Russell-Smith, J., and C.P. Yates. 2007. Australian savanna fire regimes: context, scales, patchiness. Fire Ecology 3(1): 48-63. doi: 10.4996/fireecology.0301048

Scott, A.C., D.M.J.S. Bowman, W.J. Bond, S.J. Pyne, and M.E. Alexander. 2014. Fire on Earth: an introduction. Wiley-Blackwell, Hoboken, New Jersey, USA.

Seedre, M., B.M Shrestha, H.Y.H. Chen, S. Colombo, and K. Jõgiste. 2011. Carbon dynamics of North American boreal forest after stand replacing wildfire and clearcut logging. Journal of Forest Research 16: 168-183. doi: 10.1007/s10310-011-0264-7

Serrasolsas, I., and P.K. Khanna. 1995. Changes in heated and autoclaves forest soils of SE Australia. II. Phosphorus and phosphatase activity. Biochemistry 29: 25-41.

Six, J., R.T. Conant, E.A. Paul, and K. Paustian. 2002. Stabilization mechanisms of soil organic matter: implications for C-saturation of soils. Plant and Soil 241: 155-176. doi: 10.1023/A:1016125726789

Smith, J.E., and L.S. Heath. 2002. A model of forest floor carbon mass for United States forest types. USDA Forest Service Research Paper NE-RP-722, Northeastern Research Station, Newtown Square, Pennsylvania, USA. 
Smithwick, E.A.H., M.G. Turner, M.C. Mack, and F.S. Chapin III. 2005. Post-fire soil N cycling in northern conifer forests affected by severe, stand-replacing wildfires. Ecosystems 8: 163181. doi: 10.1007/s10021-004-0097-8

Stephens, S.L., and P.Z. Fulé. 2005. Western pine forests with continuing frequent fire regimes: possible reference sites for management. Journal of Forestry 103: 357-362.

Switzer, G.L., M.G. Shelton, and L.E. Nelson. 1979. Successional development of the forest floor and soil surface on upland sites of the East Gulf Coastal Plain. Ecology 60: 1162-1171. doi: 10.2307/1936964

Wan, S., D. Hui, and Y. Luo. 2001. Fire effects on nitrogen pools and dynamics in terrestrial ecosystems: a meta-analysis. Ecological Applications 11: 1349-1365. doi: 10.1890/1051-0761(2001)011[1349:FEONPA]2.0.CO;2

Westerling, A.L., H.G. Hidalgo, D.R. Cayan, and T.W. Swetnam. 2006. Warming and earlier spring increases western US forest wildfire activity. Science 313: 940-943. doi: 10.1126/ science. 1128834

Wotton, B.M., and M.D. Flannigan. 1993. Length of the fire season in a changing climate. The Forestry Chronicle 69: 187-192. doi: 10.5558/tfc69187-2

Yanai, R.D, S. Stehman, M.A. Arthur, C.E. Prescott, A.J. Friedland, T.G. Siccama, and D. Binkley. 2003. Detecting change in forest floor carbon. Soil Science Society of America Journal 67: 1583-1593. doi: 10.2136/sssaj2003.1583

Zar, J.H. 1999. Biostatistical analysis. Prentice-Hall, Englewood Cliffs, New Jersey, USA. 